\title{
ЗДІЙСНЕННЯ В СРСР ПОЛІТИКИ ФОРСОВАНОЇ ІНДУСТРІАЛІЗАЦІЇ ТА ПОШУК ДЖЕРЕЛ ЇЇ ФІНАНСУВАННЯ (КІНЕЦЬ 1920-Х - 1930-ті pp.)
}

\begin{abstract}
Анотація: У статті досліджуються здійснення в СРСР політики форсованої індустріалізаиії, пошук джерел ї̈ фінансового забезпечення, формування централізованої економічної системи. Доводиться, що сталінська модель модернізащії Радянського Союзу за методами ї здійснення та результатами мала суперечливий характер. Зазначається, що головним джерелом сталінської модернізації став жорсткий перерозподіл усього додаткового продукту краӥни на користь важкої промисловості. Ключовим лейтмотивом радянської економічної політики 1930-х рр. було вирішення важливої історичної проблеми: зберегти незалежність і свій життєвий геополітичний простір, підтвердити статус незалежної держави.
\end{abstract}

Ключові слова: СРСР, індустріалізація, промисловий розвиток, п’ятирічка, автаркія, «Торгзін», валюта, хлібозаготівлі

Період 1929-1930 рр. багатий на події як у вітчизняній, так і у світовій історії. У 1929 р. в СРСР розпочався «великий перелом», що ознаменував собою прискорений економічний і промисловий розвиток країни. У квітні 1929 р. було прийнято перший п'ятирічний план розвитку народного господарства СРСР, що передбачав амбіційні рівні капітальних інвестицій та імпорту. У результаті різко посилюється централізоване планування, запроваджувалася жорстка регламентація кредитних та інших фінансових операцій, обмежувалися прояви ініціативи та самостійності. Країна входила у період модернізації, здійснювалося застосування нових технологій і ломка традиційних відносин. Вже у 1929 р. радянська влада змушена була запровадити карткову систему розподілу хліба й інших продуктів харчування, а згодом і промислових товарів.

У жовтні того ж таки 1929 р. біржовий крах у США став точкою відліку для найбільшої економічної кризи ХХ ст. - Великої депресії. СРСР, за рахунок своєї слабкої інтегрованості до світової економіки, практично не постраждав. Криза ставала до певної міри шансом для СРСР: в умовах скорочення світового попиту на продукцію передових галузей промисловості Країні Рад випадав шанс отримувати передові західні технології за зниженими цінами.

Метою дослідження є актуалізувати проблеми шляхів і засобів здійснення політики модернізації в СРСР, показати пошук державою джерел ї̈ фінансування, оскільки у період індустріалізації Радянський Союз переживав динамічну трансформацію в економічній і

\footnotetext{
"Священко Зінаїда Василівна - доктор історичних наук, професор кафедри всесвітньої історії та методик навчання Уманського державного педагогічного університету імені Павла Тичини (м. Умань, Україна); ORCID: https://orcid.org/0000-0001-5845-3115; e-mail: szv09@meta.ua
} 
соціальній сферах. Зміна технологічної бази радянського суспільства супроводжувалася посиленням капітальних інвестицій за рахунок села та здійснювалася в умовах ломки ринкової системи і заміни її на централізовано-плановану. Наздоганяюча модернізація повинна була проходити в умовах передових, відповідно до марксистської теорії, соціальних інститутів: план дозволяє розумно і на науковій основі розподіляти ресурси, захищати від анархії ринкових відносин і криз, що переслідують капіталістичну систему.

Основне завдання, яке ставилося радянським керівництвом - зробити економіку СРСР незалежною від капіталістичного світу, позбутися імпорту, перейти на промислове самозабезпечення. I це були не тільки доктринальні установки, а й реалії тогочасного економічного життя країни. Окрім більшовицьких ідеологічних гасел і формування соціальних інститутів, СРСР гостро потребував передових технологій, придбати які можна було лише за кордоном. Однак страх перед можливістю реставрації капіталізму та втрати завоювань соціалістичної революції диктував програму прискореної індустріалізації, примат важкої мілітаризованої промисловості та призвів до формування радянської економіки з елементами автаркії․ Цей страх відбивався й у промовах Й. Сталіна наприкінці 1920-х рр.: «Ми відстаємо від передових країн світу на 50-100 років. Ми повинні пробігти цю дистанцію за 10 років, інакше нас зімнуть»².

До застосування політики автаркії керівництво СРСР підштовхували принципи радянської торгівлі загалом і умови економічних контактів Радянського Союзу з країнами Західної Європи і США зокрема. Радянський уряд апріорі не користувався авторитетом серед потенційних кредиторів, поховав цю надію і на перспективу, відмовившись відшкодовувати борги урядів колишньої Російської імперії та націоналізувавши усю приватну власність. Тому, передбачаючи провальність проекту, Кремль навіть не робив спроби домовлятися про закордонні кредити для закупівлі устаткування для нових заводів. В СРСР намагалися покривати валютний дефіцит за рахунок внутрішніх резервів. Ці резерви, які можна було перетворити у реальні гроші (валюту), ховалися у селі. Зерно було одним із небагатьох експортних товарів, яким радянська влада могла подолати валютний дефіцит.

Рішення щодо застосування політики автаркії належало особисто Й. Сталіну й демонструвало його бажання не залежати від світової економіки у випадку потенційної конфронтації. Практично умови для політики автаркії були закладені ще в дореволюційній економіці, яка фінансувала експорт сировини (бавовнику, вовни, кольорових металів тощо) за рахунок експорту зерна. На початку 1930-х рр. експорт так і не зміг досягти дореволюційного рівня, що відображало, з одного боку, загальну тенденцію відносно слабкої міжнародної торгівлі у період між двома світовими війнами, а з іншого - нездатність радянського уряду справитися з хлібозаготівлями, які періодично виходили 3-під контролю у 1920-х рр. і призводили до необхідності покривати дефіцит короткостроковими позиками ${ }^{3}$.

Починаючи з 1927 р. умови торгівлі для СРСР стабільно знижувалися, досягнувши свого дна у 1934 р. На один долар експорту в 1934 р. можна було купити лише 2/3 того, що

\footnotetext{
${ }^{1}$ Авта́ркія (грец. autárkeia - самовдоволення) - система економічної незалежності країни, що позбавляє необхідності ввезення найважливіших продуктів споживання. - Прим. ред.

${ }^{2}$ Верхотуров Д. Экономическая революция Сталина. Москва: Олма-Пресс, 2006. С. 9.

${ }^{3}$ Шестаков Д.Е. Значение внешней торговли в экономическом росте СССР в годы первых пятилеток. Вестник Челябинского государственного университета. Серия «История». 2013. № 36 (327). Вып. 58. С. 59.
} 
було доступно у 1927 р. Ціни на зерно та природні ресурси падали разом 3 цінами на промислові товари, але останні дешевшали значно повільніше. Тому стратегією Кремля ставало зниження залежності СРСР від закордонного імпорту, з одного боку, і зниження залежності експортної виручки від хлібозаготівель - з іншого. Більша частина виручки за планами першої п'ятирічки повинна була надійти від продажу лісу, нафти й інших ресурсів. Однак, домогтися останнього не вдалося. Продукція сільського господарства у роки першої п'ятирічки стабільно становила більше 60\% експортних надходжень ${ }^{4}$.

Криза хлібозаготівель 1927-1928 pр. спонукала сталінське керівництво шукати способи зробити продаж зерна за кордон безперервним і стабільно наповненим процесом. Купівля у селян хліба за ринковими цінами звела б нанівець і без того скупий бюджет індустріалізації. Оскільки питання про згортання чи навіть зниження темпів індустріалізації радянською владою не допускалося, то село і його мешканців принесли в жертву індустріалізації, промисловому скачку та політиці автаркії. Політика колективізації й імпортозамінної економіки, запрошення на роботу іноземних технічних спеціалістів були покликані максимально сприяти модернізації країни.

Однією з ключових проблем періоду так званої «ранньої індустріалізаціі» була відсутність кваліфікованих кадрів. У кінці 1920-х рр. в СРСР виникла об'єктивна необхідність залучення іноземної техніко-технічної допомоги. Радянський Союз укладав договори про технічне сприяння 3 провідними американськими фірмами, закуповував найновішу техніку, запрошував фахівців і кваліфікованих робітників. Найбільш вдалим прикладом використання зарубіжних фахівців в індустріальному розвитку країни було тривале співробітництво радянської фірми «Амторг» з фірмою американського архітектора А. Кана, 3 яким у лютому 1930 р. було підписано угоду. Фірма А. Кана ставала головним консультантом радянського уряду з промислового будівництва й отримала пакет замовлення на будівництво промислових об'єктів вартістю 2 млрд. доларів. Це близько 250 млрд. доларів у сьогоднішніх цінах. Ця фірма забезпечила будівництво близько 500 об’єктів промисловості в СРСР.

У Москві було відкрито філію фірми А. Кана під назвою «Держпроектбуд». Тут працювало 25 провідних американських інженерів і майже 2,5 тис радянських співробітників. На той час це було найбільше у світі архітектурне бюро. Фірма А. Кана відігравала роль координатора між радянськими замовниками і сотнями західних кампаній, які поставляли устаткування та консультували будівництво окремих об'єктів ${ }^{5}$. Такий тандем між США і СРСР був взаємовигідним. США у цей час переживали Велику депресію і, як писав у лютому 1930 р. журнал «Business Week»: «Росія, будучи політично невизнаною 3 боку Сполучених Штатів, ...прийшла на допомогу американській промисловості у період ії глибокої кризи» ${ }^{6}$.

Світова економічна криза 1929-1933 рр. практично співпала у часі з періодом форсованої індустріалізації в СРСР. Вона не зачепила радянське господарство завдяки його ізольованості. Цим фактично було створено умови для того, щоб зарубіжний бізнес роз-

\footnotetext{
${ }^{4}$ Кондрашин В.В. Голод 1932-1933 годов. Трагедия российской деревни. Москва: РОССПЭН, 2008. С. 192.

${ }^{5}$ Ильюхов А.А. Вынужденая автаркия: исторический опыт. Актуальные проблемы экономики и права. 2015. № 1. C. 28.

${ }^{6}$ Who Is Getting These Russian Orders? Business Week. 1930. February 15.
} 
вернувся обличчям до СРСР і розпочав активне економічне співробітництво. Виграш від цієї співпраці був обопільним. Зокрема, Радянський Союз отримав доступ до сучасних закордонних виробничих технологій. Завдяки договорам про технічну допомогу іноземними фірмами передавалися виробничий досвід, ліцензії, патенти, надсилалися фахівці для надання консультативних послуг з будівництва і запуску в експлуатацію промислових об’єктів, а також здійснювався допуск радянських інженерів на зарубіжні підприємства ${ }^{7}$.

Для провідних західних країн реалізація Радянському Союзу різноманітної продукції та послуг у критичний період Великої депресії допомогла утримати на плаву базові галузі економіки від колапсу. Наприклад, у 1931 р. СРСР закупив у Великій Британії половину вироблених там металорізальних станків. У 1932 р. 64\% експорту металообробного устаткування США відвантажувалося до СРСР .

Особливістю зовнішньоекономічної взаємодії з країнами, які виступали технологічними «донорами», полягала у здійсненні Радянським Союзом індустріалізації за власні кошти. Ї̈̈ головним джерелом виступали внутрішні ресурси, що формувалися у результаті посилення норми накопичення (40\% до 1931 р.), перерозподілу додаткового, а часто й основного продукту низки секторів економіки на користь промисловості. У першу чергу, обділеними залишалися сільське господарство та соціальна сфера. Вже до 1933 р. п'ятирічний план 3 нарощування інвестицій було перевиконано на 1/3, а об'єм капіталовкладень за першу половину 1930-х рр. перевищив сумарний результат попередньої історії країни?.

Постійними завданнями був пошук валютних коштів для закупівлі імпортного обладнання та промислової сировини. Основним джерелом оплати імпортного устаткування і технологій виступав експорт сировини, дорогоцінних металів, предметів мистецтва та продовольства. Кон'юнктура ринку в період світової економічної кризи для експорту цих товарів була найбільш сприятливою. Однак експортні можливості СРСР були досить обмеженими. До того ж, у період світової депресії відбулося різке падіння світових цін на сировину та продовольство. Експортний план вдалося виконати за рахунок збільшення вивозу продукції сільського господарства. Максимальний об’єм експорту зерна було зафіксовано у 1931 р. - 5,1 млн. т. Та в умовах низьких світових цін збільшення об'ємів не давало зростання вартісних показників. Кожну придбану машину доводилося оплачувати у 2-2,5 рази білышою кількістю сировини та матеріалів, ніж це передбачалося ${ }^{10}$. Виконання плану експорту по сільськогосподарській продукції на 167\% в умовах трикратного зниження цін на світових ринках не давало бажаних результатів. В експортному плані це склало 10\%, у той час як виконаний план 3 поставок продуктів тваринництва, лісу, нафтопродуктів також склав відповідно 10, 15 і 16\% ${ }^{11}$.

Той же курс і структура експорту зберігалися й на початку другої п'ятирічки (1933 р.). Більше третини його становила сільськогосподарська продукція, для якої ринкова кон'юнктура була найменш сприятливою. За фізичним об'ємом вивезення зернових

\footnotetext{
${ }^{7}$ Шпотов Б.М. Американский фактор в индустриальном развитии СССР, 1920-1930-е годы. Москва: Ин-т экономики РАН, 2009. С. 18.

${ }^{8}$ Мальщев А.А. Форсированая модернизация советской экономики: «демодернизация» или индустриалный прорыв? Известия УрГЭУ. 2010. № 6 (32). С. 94.

${ }^{9}$ Белоусов Р.А. Экономическая история России: ХХ век: в 3 кн. Москва: ИздАТ, 1999. Кн. 3. С. 104.

${ }^{10}$ Медведев Р. О Сталине и сталинизме. Знамя. 1989. № 2. С. 177.

${ }^{11}$ Осокина Е.А. За зеркальной дверью Торгсина. Отечественная история. 1995. № 2. С. 88.
} 
зберігалося на рівні 1932 р., а за показниками вартості становило 78\% від нього. Упродовж другої п'ятирічки здійснювалося згортання зовнішньоекономічних зв'язків СРСР. У цілому, об’єм зовнішньої торгівлі скоротився удвічі. Причинами цього стала поява нових контрагентів на світовому ринку, стрімке згортання економічних відносин з Німеччиною після приходу до влади А. Гітлера, політика автаркії, яка стала домінуючою на фоні певних успіхів індустріалізації ${ }^{2}$. Крім того, неврожаї 1930-х рр. і необхідність продовольчого забезпечення міського населення, що різко зросло (з 26 млн. до 38,7 млн. осіб за 19261932 рр.) до 1934 р. фактично обнулили експорт зерна ${ }^{13}$.

Перехід до прискореного індустріального розвитку похитнув і стабільність карбованця, яка надзусиллями набувалася у роки нової економічної політики. Розрив між грошовою масою та її товарним забезпеченням вилився у гострий товарний дефіцит. У 19311935 рр. розподіл товарів здійснювався за картковою системою з різними нормами на продукти і промислові товари для груп населення.

Згортання зовнішньоекономічних зв'язків не знімало питання про надходження валюти для здійснення програми індустріалізації. Ї̈̈ вирішили шукати всередині країни. Важливим джерелом засобів, які допомогли згладити відмову від імпорту іноземної продукції, став «Торгзін». У 1930 р. при Наркоматі торгівлі було створено контору по торгівлі 3 іноземцями всередині СРСР («Торгзін»). В умовах запровадження карткової системи на продукти харчування та товари першої необхідності Наркомат торгівлі було реорганізовано у два наркомати: Наркомат постачання та Наркомат зовнішньої торгівлі. У системі «Торгзіну» організовувалася мережа магазинів закритого типу, які реалізовували гостродефіцитні продовольчі та промислові товари. Спочатку «Торгзіни» обслуговували лише іноземців, які перебували в СРСР з короткочасними візитами та мали картку «Інтуриста», або транзитну візу. Розраховувалися іноземці квитанціями, отриманими під час обміну валюти, або валютними чеками Держбанку, які той продавав за валюту ${ }^{14}$.

У результаті організації таким чином діяльності «Торгзіну» його доходи були незначними, оскільки туризм в СРСР був розвинений слабо. Тому вже з 1931 р. розширилася географія «Торгзіну» і в його роботі з'явилися нові форми - експорт антикваріату та шипчандлерство (забезпечення іноземних суден у радянських портах). «Торгзін» також отримав право вивезення та продажу за кордоном предметів старовини та розкоші. У результаті такої афери держави музеї країни, церкви, монастирі втратили безцінні експонати та шедеври мистецтва. У 1931 р. «Торгзін» широко відкрив свої двері й для радянських покупців і став потужним механізмом викачки у населення запасів валюти, золота й інших цінностей, які за заниженими цінами обмінювалися у торгзінівських магазинах на дефіцитні побутові товари та продукти харчування. За умови здачі золота у вигляді ювелірних прикрас, начиння або монет у радянських людей з'явилася можливість купувати товари у «Торгзіні». Валютні перекази з-за кордону також відкривали можливість для користування «Торгзінами». Якщо з початку своєї організації «Торгзіни» торгували продукцією вітчи-

\footnotetext{
${ }^{12}$ Муравьева Л.А. Промышленное развитие и финансы в годы довоенных пятилеток. Финансы и кредит. 2003. № 9 (123). С. 83.

${ }^{13}$ Внешняя торговля СССР за 1918-1940 гт.: стат. обзор / Мин-во внешней торговли СССР; Главное таможенное управление. Москва: Внешторгиздат, 1960. С. 357.

${ }^{14}$ Осокина Е.А. За зеркальной дверью Торгсина... С. 88.
} 
зняного виробництва, то з 1933 р. вони отримали право купувати товари за кордоном. Діяльність «Торгзіну» була різноманітною за формою. Його популярність зростала як всередині країни, так і за кордоном. Відповідно до деяких оцінок, у період між 1932 і 1935 рр. «Торгзін» отримав товарів на 280 млн. золотих карбованців, що співставно практично 3 третиною усього об'єму експорту у будь-якому із цих років ${ }^{15}$.

До «Торгзіну» людей гнав голод і бажання вижити, тому доходи «Торгзіну» зростали в міру погіршення продовольчої ситуації. Самим прибутковим став голодний 1933 р. Структура цінностей, що надходили до «Торгзіну», також змінювалася відповідно до ситуації. Якщо на початку 1930-х рр. майже половину надходжень становила валюта, то 3 1933 р. основним видом надходжень стали «побутові цінності». У голодні роки різко зросла здача срібла, яке «Торгзін» почав приймати нарівні із золотом. Змінювалася і структура купівлі у торгзінівських магазинах. У 1933 р. більше 80\% товарів, реалізованих «Торгзіном», становили продукти, причому 64\% припадала на хліб. У 1934 р. в покупках продовжували домінувати продукти, але частка хліба знизилася, а частка промислових товарів стала поступово та суттєво зростати ${ }^{16}$.

Нормалізація продовольчої ситуації в країні на середину 1930-х рр., скасування карток на продукти та промислові товари, зниження цін і покращення асортименту товарів у комерційних магазинах призвели до зниження інтересу радянських громадян до «Торгзінів». До того ж більша частина їх цінностей перекочувала до цих закладів. 1 лютого 1936 р. Всесоюзне об’єднання «Торгзін» припинило своє існування. Цінності, які купив «Торгзін», покрили більше п'ятої частини витрат на імпортні закупівлі 1932-1935 pр. вирішальні роки промислового стрибка. У голодному 1933 р. цінності, придбані «Торгзіном», дозволили СРСР оплатити третину, у 1934 р. - більше чверті, а у 1935 р. - майже п'яту частину радянського імпорту промислового обладнання, сировини і технологій. Загалом, золото, отримане від населення «Торгзіном», дозволило профінансувати близько третини витрат на індустріалізацію Радянського Союзу ${ }^{17}$.

Індустріалізація в СРСР відбувалася і за рахунок збереження державою низького рівня життя робітників. Невід'ємним атрибутом перших п'ятирічок (і не лише перших) було застосування примусової праці, яка з часом набула масштабів і організаційного оформлення. Значну частину цього контингенту складали засланці та спецпереселенці. Вони працювали, в основному, на Уралі й у Західному Сибіру та складалися переважно з українських «куркулів» і членів їх родин. Унаслідок зміни розміщення виробничих сил і просування у безводні степи й арктичний пояс, зросла доля такої форми примусової праці, як виправно-трудові табори з надзвичайно жорсткими умовами проживання. Масові репресії давали можливість використовувати дешеву робочу силу в екстремальних умовах. За підрахунками вчених у таборах працювало понад 25\% усіх зайнятих у матеріальному виробництві ${ }^{18}$.

Результатом прискореного промислового розвитку стала ліквідація безробіття, оскільки в СРСР запроваджувалася загальна трудова повинність. У кінці 1920-х рр. число

\footnotetext{
${ }^{15}$ Осокина Е.А. Золото для индустриализации: «ТОРГСИН». Москва: РОССПЭН, 2009. С. 109.

${ }^{16}$ Осокина Е.А. За зеркальной дверью Торгсина... С. 96.

${ }^{17}$ Осокина Е.А. Золото для индустриализации... С. 11.

${ }^{18}$ Муравьева Л.А. Промышленное развитие и финансы в годы довоенных пятилеток... С. 82.
} 
робітників і службовців у державі складало 12 млн. осіб, на обліку біржі праці перебувало 1,7 млн. осіб. Восени 1930 р. число безробітних, зареєстрованих на біржі праці, зменшилося до 200 тис осіб. У 1931 р. біржу праці було закрито, з безробіттям у СРСР було покінчено ${ }^{19}$.

Важливим зовнішньоекономічним чинником у посиленні джерел фінансування індустріалізації стала відмова Великої Британії від золотого стандарту у 1931 р. і США у 1933 р. Девальвація їх валюти знизила реальну вартість зовнішнього боргу СРСР, який був повністю оплачений до кінця другої п'ятирічки.

У всіх цих процесах, досліджених та описаних нами вище, була і позитивна сторона. Форсована індустріалізація змінила структуру радянського суспільства. Вона призвела до помітного зростання частки робітників і службовців і, відповідно, до суттєвого зменшення працівників сільського господарства. 3 початком індустріалізації у простих радянських громадян з'явилося більше шансів отримати професію ${ }^{20}$. Крім того, зарубіжні науковці, політики, діячі культури, які відвідували СРСР у цей період, об’єктивно оцінювали зміни, що відбулися у країні. Позитивні наслідки мали запровадження загальної обов'язкової освіти, прагнення радянського суспільства до оволодіння досягненнями світового технічного прогресу. Створена система охорони здоров'я зробила медичне обслуговування доступним не лише для мешканців великих міст, а й сільської глибинки ${ }^{21}$. За роки перших п'ятирічок місткість лікарень зросла втричі, чисельність лікарів - у 5 разів, подвоїлася шкільна мережа, а чисельність вчителів зросла у 6 разів. Країна отримала достатню матеріальну базу для розвитку дошкільного виховання, збільшення числа середніх шкіл, доступності середньої спеціальної та вищої освіти. Набували розвитку засоби масової інформації, популярним ставало кіно. Широкі верстви населення отримали доступ до споживання культури урбаністичного типу ${ }^{22}$.

Отже, керівництво СРСР, здійснюючи модернізацію у кінці 1920-х - 1930-х рр., вибрало найбільш складний і ресурсозатратний варіант розвитку радянської економіки. Він передбачав не лише авторитарний розвиток з опорою на власні сили, але й був обмежений курсом на максимальне форсування важкої промисловості за рахунок безпрецедентного грабежу села, стримування зростання життєвого рівня населення, гальмування розвитку соціальної сфери, вилучення у населення валюти та сімейних цінностей.

СРСР вдалося за короткий строк здійснити модернізацію промисловості. За 12 років соціалістичної індустріалізації завдяки ентузіазмові та самовідданій праці радянських людей вдалося підняти виробництво основних видів промислової продукції на новий рівень у порівнянні з дореволюційним періодом. Радянський Союз подолав відставання від провідних і високорозвинених країн Західної Європи з виробництва основних видів промислової продукції.

Сталінська модернізація в умовах створення індустріального суспільства хоча і виявилася досить ефективною, однак ціна досягнутих успіхів виявилася надзвичайно високою.

\footnotetext{
${ }^{19}$ Страна Советов за 50 лет. Сборник статистических материалов. Москва, 1967. С. 235.

${ }^{20}$ Резаненко 0.0. Американская пресса о советской индустриализации в 1920-1930-е годы. Самарский научный вестник. 2016. № 2 (15). С. 116.

${ }^{21}$ История США. Т. 3 / под ред. Г.Н. Севостьянова. Москва: Наука, 1983. С. 112.

${ }^{22}$ Муравьева Л.А. Промышленное развитие и финансы в годы довоенных пятилеток... С. 84.
} 


\title{
Zinaida Svyashchenko
}

\section{Implementing the Policy of Forced Industrialization in the USSR and Searching for Sources of Its Financing (the Late 1920s - the 1930s)}

\begin{abstract}
The article studies the processes of implementing the policy of forced industrialization in the USSR, searching for sources of its financing and developing a centralized economic system. It shows that Stalin's model of modernizing the Soviet Union with the methods of its implementation and results was rather contradictory. The key issue in the preparation of the industrialization plan was the sources for its financing and implementation. The article shows that the main source of Stalin's modernization was the rigid redistribution of all the country's additional products in favour of heavy industry. Given that it was impossible to obtain foreign loans, only domestic resources were used to finance industrialization. They involved plundering the countryside, curbing the growth of living standards, decelerating the development of the social sphere, seizing currency and family values.

An important foreign economic factor in strengthening the sources of financing for industrialization was the rejection of the UK and the United States from the gold standard. The devaluation of their currency reduced the real value of the Soviet Union's foreign debt, which was paid in full by the end of the Second Five-Year Plan.

The industrialization enabled the Soviet Union to keep pace with the leading and highly developed countries of Western Europe in the production of basic industrial products. Although Stalin's modernization in the context of creating an industrial society proved to be quite effective, the price of success was very high.

The Soviet economic policy of the 1930s was striving to solve an important historical problem, that is, to preserve independence, its living geopolitical space and confirm the status of an independent state.
\end{abstract}

Keywords: USSR, industrialization, industrial development, five-year plan, autarchy, Torgsin, currency, grain procurements 